\title{
Conflict Threats to Human Security: The Lord's Resistance Army (LRA) Case, Gulu District, Northern Uganda
}

\author{
Anne Abaho, Micheal Mawa, Solomon Asiimwe \\ Nkumba University, Entebbe, Uganda \\ Email: aabaho@nkumbauniversity.ac.ug
}

How to cite this paper: Abaho, A., Mawa, M. and Asiimwe, S. (2019) Conflict Threats to Human Security: The Lord's Resistance Army (LRA) Case, Gulu District, Northern Uganda. Open Journal of Social Sciences, 7, 64-85. https://doi.org/10.4236/jss.2019.712006

Received: October 12, 2019

Accepted: November 30, 2019

Published: December 3, 2019

Copyright (อ 2019 by author(s) and Scientific Research Publishing Inc. This work is licensed under the Creative Commons Attribution International License (CC BY 4.0).

http://creativecommons.org/licenses/by/4.0/ (c) (i) Open Access

\begin{abstract}
The study recognised that conflicts threaten human security in various ways. When prolonged, for example, they have a direct damage on physical infrastructure such as medical and educational facilities. Using a qualitative research approach, the study focused on Gulu district in Northern Uganda, to unearth the threats to human security as a result of the protracted Lord's Resistance Army (LRA) conflict. The data collection methods included: Focus Group Discussions, Interviews and Document Review. Samples of 44 participants were purposively identified. From the field findings, it was discovered that the dimensions of human security threatened by conflict ranged from personal, health and community security. The study recommended that there needs to be a deliberate effort in the post-conflict period to rehabilitate infrastructure especially schools and hospitals while counselling services should be supported to mitigate the psychological effects of the conflict.
\end{abstract}

\section{Keywords}

Conflict, Human Security, Gulu District, Northern Uganda

\section{Introduction}

“... majority of the people if not all are traumatized and cannot sleep because of painful memories ... IDPs have limited access to land and few opportunities to generate income, services have largely collapsed ... inadequate water supplies and sanitation facilities, limited access to health care ... HIVIAIDS orphans, domestic violence and sexual abuse distress the war affected population, intensified by conflict, displacement and camp life ..." [1].

The intension of this research is to analyse the dimensions of human security 
that are threatened by conflict. Certainly, the quotation above speaks volumes about the threats to human security resulting from conflict ranging from health to housing difficulties. Although there was remarkable hope with the ending of the Cold War for peace across the globe, [2] remarked that the end to East-West tension did not really usher in an end to conflict but instead an increase in the same. Indeed, between 1989 and 2001, not less than 115 armed conflicts occurred in several parts of the international system [2]. Contrary to these writers' observations though is the [3] that documented that armed conflicts had reduced in the last 15 years. Despite the contradiction, what is evident is that conflict is not limited to any part of the global system and Africa is hence, no exception. The continent has suffered a series of conflicts ranging from the wars of independence in Southern Africa to the 1960 Katanga and 1967 Biafra secessionist conflicts; intra-state rebellions that start often as guerilla movements against governments with hopes of taking power such as the Lord's Resistance Army (LRA) in Uganda to inter-state conflicts such as the Nigeria-Cameroon conflict over the Bakassi Peninsular and Ethio-Eritrean war among others. Such wars leave deep scars on the social fabric and unless major progress is done in addressing the conflicts in the continent, it is unlikely that any International Development Goals can be achieved [4]. In light of the discussion at hand, it is worth for the reader to understand how the LRA cropped up.

\subsection{The Lord's Resistance Army Conflict: Background}

The LRA, is said to have emerged in 1987 as a counter to the National Resistance Army (NRA), a Western Uganda dominated force led by Yoweri Kaguta Museveni [5]. The [6] explained that the ethnic composition of the post-independent Uganda leadership contributed significantly to the support rendered to the LRA. For example, the [6] narrated how the 1962-71 Obote regime relied heavily on the Langi and Acholi to stay in power. Unfortunately, these (Langi and Acholi) became targets of killing when Amin took over power in 1972 including the 1977 murder of Anglican Archbishop of Uganda. He (Amin) replaced the Acholis with the West Nilers especially Kakwa and Aringa [7]. With such ethnic favouritism, the stage for political crises in the country was set and probably worsened with the coming of the National Resistance Army (NRA) in 1985. The National Resistance Army (NRA) rebellion, noted [8] marked significantly the beginning of the North-South divide when a group of Southerners, many of whom were in exile found it necessary to remove Northerners from national power and end a Northern military dictatorship. Against the loss of power and military humiliation to the NRA, the Northerners felt betrayed and fought to regain their political positions [7]. It is in such a political environment that Kony emerged and despite his military incompetence was largely followed by the Acholis. [1] explained that the Northern Uganda war was characterized by massive displacement, killings, abductions of innocent children, property and infrastructural destruction among others. In addition, thousands of people were maimed permanently while others suffered mutilations of limbs, noses, arms and other body 
parts. [1]'s description of the war is in line with the [6]'s submission that the conflict was exceptionally protracted and brutal in its impact on civilian population.

\subsection{Conceptual Analysis: Conflict, Security and Human Security}

\subsubsection{Conflict}

In 1990, Burton expressed that conflicts are behaviours with a potential of being destructive of persons, properties and systems [9]. Conflict can as well be defined as a struggle or contest between people with opposing needs, ideas and beliefs, values and goals [10]. From the definition, conflict is not necessarily associated with violence. Yet, despite the fact that conflict is a universal feature of human society and manifests in economic differentiation, social change and cultural transformation [11], what is irrefutable is that when characterized by physical violence and left to escalate, it leads to destructive results. The destructive nature of conflict is normally reflected in loss of life, property destruction and displacement.

\subsubsection{Human Security}

The year 1994 is articulated as the first major global acceptance of the concept of human security with the production of the United Nations Development Program (UNDP)'s report: New Dimensions of Human Security [12]. However, the interest in human security especially by the United Nations had already taken root in 1993 in the [13]'s Human Development Report-People's participation. The Report made reference to some major prerequisites to enjoyment of human security including people's active involvement in determining their destinies and that there can be no human development without people's participation. For this to happen, the [13] argued that there should be reconceptualization of the major International Relations principles including security. It recorded:

“... Many old concepts must now be radically revised. Security should be reinterpreted as security for people not security for the land ... the concept of security must change from an exclusive stress on national security to a much greater stress on people's security ... from territorial security to food, employment and environmental security ..." [13].

Today, the non-traditional threats to security are a challenge to the classical realist approach to security which considers the military as an only guarantor of security.

According to the [14], Human Security is:

"... protection of fundamental freedoms-freedoms that are the essence of life. It means protecting people from the critical (severe) and pervasive (widespread) threats and situations. It means using processes that build on people's strengths and aspirations. It means creating political, social, environmental, economic, military and cultural systems that together give people the building blocks of survival, livelihood and dignity" [14].

The definition indicates a significant break from the State as the referent ob- 
ject with people at the centre. Different from the State approach, the peoplecentered approach takes a multi-sectoral view in understanding insecurities and includes causes of insecurity ranging from economic, food, health, environmental, personal, community and political factors. The [15] in its Human Security in Theory and Practice, the components of human security and the possible types of human security threats were identified as indicated in Table 1 .

\subsection{Statement of the Problem}

Conflicts are recorded to have enormous threats to human security because of their destructive nature on lives, properties and sources of livelihood [16]. Yet, despite the destructive nature, a number of countries especially in the global South are not only stuck in conflict cycles but are also battling with the legacy of violence [17]. In explaining the threats to human security resulting from conflict, [18] recorded that broadly, conflict obstructs human security in terms of loss of life; destruction of livelihood sources, violation of basic dignity indicators such as forcing women into prostitution and destruction of social services including health and education. Notably, the LRA conflict caused massive displacement of an estimated $85 \%$ of the population into Internally Displaced Persons (IDPs) camps [19]; exacerbated levels of gender based violence and recruitment of about 25,000 children as combatants, laborers and sex-slaves [20] as well as reduced economic benefits due to property destruction and trade losses. The [21] listed poverty, displacement, losses due to cattle rustling, loss of productivity, increased cases of HIV/AIDS and decline in regional opportunities as the indicators of human insecurity in Northern Uganda resulting from the LRA conflict [21]. According to the Gulu District Local Government Report (2012), the district has, as a result of conflict, suffered from low numbers of qualified teachers (2860 out of 8266 primary teachers in Acholi region) [22]; few points of clean and safe water (958 for Gulu Municipality) and few health facilities (2 health Centre IVs, 2 government hospitals-Gulu Main and Uganda Military Hospital).

Table 1. Human security types and possible threats.

\begin{tabular}{ll}
\hline \multicolumn{1}{c}{ Type of Security } & \multicolumn{1}{c}{ Example of Main Threat } \\
\hline 1) Economic Security & Persistent poverty, unemployment \\
2) Food Security & Hunger, famine \\
3) Health Security & $\begin{array}{l}\text { Deadly infectious diseases, unsafe food, malnutrition, lack of access } \\
\text { to basic health care }\end{array}$ \\
4) Environmental Security & $\begin{array}{l}\text { Environmental degradation, resource depletion, natural disasters and } \\
\text { pollution }\end{array}$ \\
5) Personal Security & Physical violence, crime, terrorism, domestic violence and child labor \\
6) Community Security & Inter-ethnic, religious and other identity-based tensions \\
7) Political Security & Political repression, human rights abuses \\
\hline
\end{tabular}

Source: [15]. Human Security in Theory and Practice. 
Against the context above, this work seeks to analyse the different dimensions of human security threatened by conflict.

\section{Literature Review}

\subsection{Human Security Dimensions Threatened by Conflict}

Conflict threatens human security in a number of ways ranging from displacement, destruction of property and economically productive livelihoods to collapsing public infrastructure such as education, health and water as well as breakdown in socio-cultural norms [23]. In line with Reinke, is [21] Report which pointed out: political/security, socio-economic and humanitarian costs as the key consequences of the conflict. In the next section a detailed analysis of the conflict threats is undertaken.

\subsection{Community Security Dimension}

\section{Shift in Authority/Social Structure}

Social cohesion is the foundation for collective identity and is as such a factor for mitigating tensions and conflict in society [24]. Unfortunately, conflict shatters the different forms of social cohesion, shifts social values and profoundly disorganizes old and new generations. In support of [24] is the [14] which emphasized that conflict erodes trust in people, communities and government institutions and undermines as well social cohesion. The [25], referring to Mozambique, Rwanda and Sierra Leone narrated how conflict short circuits the rules that keep human interaction constructive and predictable while primarily targeting organizations and individuals that administer those rules. The ACBF warned that once the reputation for honest interaction has been lost, the incentives for honest behaviour in future are also greatly weakened.

Pre-war Acholi societies were majorly organized along lineage and clan-based patriarchal structures [8]. Such social organization is not a unique characteristic of the Acholi societies as it is a feature of other societies in Africa such as Somalia. For example, [26] argued that clans gave Somalis a sense of identity until the arrival of clanism (ethnic version of Somali politics) after independence. While in Somalia it is ethnic politics that created disorder, in Northern Uganda, it is the breakdown of the lineage structures resulting from conflict that led to disintegrated social relations. For example, with the war, movements were restricted making clan meetings impossible while displacement led to disintegration of clans. Of course, many of clan leaders and elders died during the war presenting many problems beyond the resolution capacity of the surviving leadership. Without doubt, conflict threatened community and personal security.

\subsection{Destruction of Physical and Social Infrastructure}

The [21] acknowledged a disruption of basic social service delivery resulting from war. Indeed, as [27] explained, destruction of infrastructure is the most visible consequence of conflict. In confirmation with [27], [28] asked their res- 
pondents the priorities for post conflict state building in South Sudan, and more than $90 \%$ emphasized the desperate condition in which infrastructure and social amenities were. Infrastructure especially roads and electricity, social services such as schools, hospitals and clean water are normally the greatest affected by conflict. Unfortunately, as citizens remain trapped in extreme poverty and hopelessness, in the post war environment, they can easily be exploited by war loads and other figures to engage in armed violence [27]. In the next section, emphasis is put on examination of how conflict destroys the mentioned infrastructure.

\subsubsection{Health}

The first principle of health is life. Unfortunately, conflict is a direct threat to both health and life. [29] noted that conflicts do not only impact on the health of the affected population but also the health structure and social determinants of health. This view is supported by [30] who hold that apart from the conflict related deaths and injuries on the battlefield, conflict registers health consequences resulting from displacement of populations and breakdown of health and social services as well as the heightened risk of disease transmission. [30] added that conflict equally causes disability with the disabling effects of landmines being one manifestation.

In Somalia, [31] explained how men affected by conflict became addicted to khat due to trauma, unemployment and financial dependency on others. This addiction unfortunately had an impact on their mental and general health. Trauma is seen as a direct impact of conflict on individuals together with the numbers killed, injured and disabled. Unfortunately, trauma and psychological impact of suffering largely go unattended especially in countries where provision of health services is already compromised. Thus, traumatized conflict survivors are likely to feel a sense of shame, hopelessness and mistrust that can lead to criminal activity, domestic and gender-based violence [14]. The health impacts of conflict are probably largely felt by children during and after conflict periods [32]. Regrettably, children bear the health implications even way beyond the conflict as a result of exposure to infectious diseases, acute malnutrition and general poor sanitation. This view was confirmed by [33] having interviewed 3030 children aged 8 - 9 years from Rwanda after the genocide and found that many were still traumatized by the genocide events. The authors attributed this to witnessing the killing of their loved ones, dead bodies and destruction of their homes. In equal measure, [16] confirmed that children and young adults are particularly vulnerable to shocks during armed conflict leading to mental and physical challenges. Referring to Northern Uganda, the [34] recorded in line with the effects of conflict on health the following:

"Continued exposure to violence and repeated child abductions, soaring mortality have led to high levels of trauma among the population. Depression and post-traumatic stress disorder are becoming more common while suicide, a cultural taboo is a growing phenomenon as the burden of daily struggle becomes too much for many." 
This unfortunately has lasting consequences on the life of the individual many years after the end of the conflict. Worse still, in the post-conflict environment, feelings of revenge may lead to a return to chaotic situation.

\subsubsection{Water}

There is a very undeniable link between water and conflict. Indeed, uneven water resources distributed in different areas coupled with increase in population have created tensions that in turn become conflictual. This is evident in regions prone to competition between pastoralists and farmers over agricultural and grazing land resulting from environmental factors. It is noteworthy that while water scarcity can lead to conflict, the latter can also lead to loss of or destruction of the former. Indeed, as the [14] intimated, without water, survival-human or otherwise becomes impossible.

In 2009, the [35] explained the impact of conflict on water as a fundamental element in the realization of human security. Reference was made to the 2006 Lebanon crisis during which wide spread bombing destroyed water supplies and sanitation facilities and later led to an outbreak of diarrhoea [35]. The Review also made mention of the key elements: water, sanitation and hygiene in ensuring the health, development and welfare of children. It actually attributed the death of at least one quarter of all children to inadequate access to safe water and sanitation services combined with poor hygiene practices. It is fundamental to note that during conflict, chances of finding safe water become very narrow while sanitation and hygiene become no longer a priority.

\subsubsection{Education}

[36] wrote that the longer-term effects of conflict include the continuing loss of educational years, challenges in comprehension and delivery due to psychological trauma on both students and teachers, extended period of shortages in infrastructure teacher shortages caused by death, fleeing the country and disruption of teacher training. Conflict directly also affects schooling through attacks on students and teachers [37] especially for use as members of the combat groups.

[24] in a tone that supported [36] brought to light the consequences of conflict on education in Northern Uganda. The duo wrote that to mitigate the war effects on education, the Government of Uganda mandated establishment of makeshift schools in form of "learning centres" inside the camps. Such centers, however, together with the village schools struggled to stay intact while facing daunting challenges including overcrowding, lack of basic hygiene such as water and latrines, collapsed school management systems, inadequate instructional materials and widespread trauma among both students and teachers [24] [37] writing about the learning centres mentioned how in Kitgum, for example 140 schools were reorganized into 34 learning centres. Worst, Gates explained that it was not clear who was responsible for construction of these centres but responsibility seemed to have been left to the community and especially the students' parents. It is appropriate to note that the effects of conflict on education have far-reaching 
implications. Certainly, education is not just about literacy and numeracy but it can give people knowledge about health, hygiene and nutrition in addition to basic skills necessary for human survival.

Conflict exacerbates pre-existing levels of education inequality between groups as well as inequality across all individuals in a given country [38]. Regrettably, it may also be very challenging to decrease education inequality in the post conflict years between the areas that were affected and those that were not. While [38] argued that the effect of the conflict on education may be largely dependent on length of conflict and its nature (ethnic or otherwise), they admit that by and large, conflict is detrimental and the levels of inequality cannot be expected to return to pre-conflict levels of their own. Without doubt, the conflict effects on education have long term effects reflected in limited earning due to lack of formal employment opportunities and profound health challenges during adulthood.

\subsection{The Humanitarian Cost}

Conflict strongly compromises the realization of personal, community and political security through exposing the individual and different communities to massive abuse of human rights especially the right to life. Indeed, [39] made reference to the Boko Haram terror activities that caused a humanitarian catastrophe for women, girls and children. This work holds that while conflict is by its very nature destructive and its effects non-discriminative, women and children become the greatest victims. Today, the civilian population generally is at the forefront of warfare and thus is subjected to systematic attacks by States, armies and violent non-state actors alike. That men and women are differently affected by conflict can be attributed to the subdivision of social roles that are reinforced by society from childhood to maturity. These enable creation of lines of distinction between masculinity and femininity. Thus, aspects of bravery, toughness and aggressiveness are encouraged among men while raising families and nurturing children are encouraged among girls.

War places double burdens on women as many do not only have to defend their nations physically but also replace men and carry both feminine and masculine roles. Women headed households are particularly vulnerable especially where the law doesn't allow easy access to and control over land [40]. Agreed, by their very nature and the socialization process, men are the direct victims of conflict. However, indirectly conflict affects women due to its militarized effects such as reduced access to food, hygiene, health services and clean water from which women suffer more severely than men [41].

Women are among the poor and vulnerable groups that may not be able to access Government services and escape from poverty [39]. It is equally true that women may be stuck in poverty even after conflict due to their dependence on land which, in customary practices they do not control and may not be allowed to inherit in case of the husband's death during conflict. Lack of ownership of land limits the purchasing power before and during conflict but may worsen it 
after conflict as the pre-existing gender relations create extra burdens in accessing water, food among others. [41] also alluded to the sexual violence effect of conflict that holds that women and girls become victims of sex trafficking just as they are forced to serve in military brothels or endure some form of sexual slavery. [40] mentioned that in the GLRA, Sexual and Gender Based Violence [SGBV] is increasingly being used as a weapon of violence. SGBV whether in conflict or peaceful times has devastating effects including physical injuries, death, loss of esteem as well as psychological and emotional defects.

The section on literature review has discussed in detail the threats to human due to conflict. These threats range from infrastructural collapse such as health facilities and a humanitarian impact. It is worth recording that when human security is compromised, so too may development and attainment of other global goals such as development and peace.

\section{Methodology}

The study opted for a non-positivist research perspective that encourages understanding and interpretation of social reality subjectively as each event may mean differently to different people [42]. As such, the interpretation and derivation of meaning from any given events that may appear related can as well have different meanings in view of the context, social forces and actors involved. Hence, for non-positivists, social actions and experiences do not exist in themselves but are rather dependent on their recognition and interpretation by social actors [43].

Following the non-positivist research paradigm, realism was preferred as the research philosophy. Realism, as used in this research is different from the commonly referred to International Relations Theory that values military power as a guarantor of State security. As used in this study, realism considers that reality is not necessarily connected to the researcher's mind. For realists, such an approach allows the researcher to make credible observations in for example, single cases to determine causation without necessarily comparing situations [44].

The study took a qualitative approach because it allows a deeper understanding of the meaning and nature of people's experiences regarding different problems and provides room to obtain intricate details about phenomena. Hence as opposed to a quantitative approach that lends itself more to causation, the qualitative approach appreciates feelings, thought processes and emotions that may be difficult to understand in more conventional research ways [45]. This approach allowed the researcher to study the threats to conflict by interacting with those that lived through the conflict years (returnees) and gave opportunity to the researcher to understand and interpret meanings, expressions and experiences of the participants. The richness of the qualitative approach in research was appreciated by [46] when he advised that for one to be able to obtain a complex, detailed understanding of an issue which (detail) can be best established by talking directly with people, going to their homes or places of work and allowing them to tell their stories unencumbered by what we expect to find or what we 
have read in the literature, a qualitative research approach should be adopted.

Using Gulu District as a case study, an indepth analysis of the problem was conducted. Gulu district was preferred because of its central position during the LRA conflict. The district suffered attacks from the LRA and counter attacks from the Uganda Peoples Defense Forces (UPDF) that in turn affected human security. The [47] explained that Gulu town for example became a base for rebel attacks and due to the terror unleased on the citizens in the periphery areas, it turned out to be a destination for the night commuters.

Using purposive sampling technique, participants were selected basing on their knowledge of the subject under discussion. The study had a sample size of 44participants. The use of purposive sampling allowed the researcher to capture a wide range of views from knowledgeable participants until the point of saturation. The saturation point was reached in the fifth Focus Group Discussion (FGD) during which threats to human security such as collapse of health and educational infrastructure as well as loss of life were repeated. As advised by [48], the Maximum Variation Sampling (MVS) strategy was adopted in order to allow a wide range of participants. Indeed, the selected respondents (returnees, Chief Administrative Office, Local Council V, Uganda Police Force, Civil Society Organizations, Traditional and Religious leadership as well as Office of the Prime Minister) had a variety of variations such as gender and age.

A number of data collection methods such as interviews and Focus Group Discussions were used. Correspondingly, the interview guide and the Focus Group Discussion guide were used as the data collection instruments. Interviews, as explained by [49] allowed collection of data that captured views, emotions and opinions as opposed to mere reporting in a word or two. In total, 14 interviews with key informants (including Office of the Prime Minister staff, Police, Local Council leadership, Religious and traditional leadership) were held.

Equally, the researcher held 5FGDs and as advised by [49], the composition of each was 5 - 10 participants. Hence, 30 participants were involved in the FGDs. True, FGDs are discouraged because of the limited number of questions one can address and the problem of taking notes during the interview [50]. However, they are encouraged because of being less costly and yet rich in data as well as allowing the researcher to study the interaction among the participants and how they influence each other's expressed opinion [51].

These methods were used in support of the Document Review technique guided by the Document Review Checklist. Among the documents reviewed were: donor/development partners' reports such as the [52]; Office of the Prime Minister's Reports such as [21] [53] and [22]. The researcher designed a consent form upon which study participants consented. Bearing in mind the educational effects of the conflict, the consent form and FGD guide were interpreted into the local language and read to participants using the native language. From the methods used, the research identified a multitude of threats to human security from conflict as the discussion below indicates. 


\section{Discussion of Findings}

\subsection{Threats to Community/Group Security}

A wide range of literature [14] [21] [24] exists explaining how conflict affects the community/group dimensions of human security. In the sections that follow, these are elaborated.

\subsection{Destruction of Social Norms}

In one of the Focus Group Discussions, as a respondent explained the magnitude of the threat due to displacement, others nodded in agreement. He voiced:

"... elders in the community were killed-the Wao (traditional tale) is no more ... no more life stories ... these stories were used to pass on knowledge and the elders were highly respected-highly (with emphasis) ... things have now changed ... we used to dance to bid farewell to the dead but this has all stopped ... people now are interested in dancing to music from the discos ... may be because life became meaningless in the camp ... one would never know when they will die ..." (FGD, 25 ${ }^{\text {th }}$ August 2018).

In another Focus Group Discussion, a participant submitted in line with the above:

“... cultural norms were spoilt-elders used to sit around fire and knowledge was imparted ... girls were counselled ... boys were groomed on how to become men ... this now is no more ... we have no connection with our social past ... before the war, when you saw young girls carrying children, you would know they were carrying their siblings or were baby sitters ... this is not the case today, many are actually carrying their own flesh ... the situation is worse because without parents and guardianship, many children are marrying at lower ages ... the process of courtship has died and the girls will run to marry thinking it will free them from poverty ..." (FGD, $8^{\text {th }}$ September, 2018).

In 2011, [54] had recorded that in pre-war Acholi societies; lineage was majorly organized along clan-based patriarchal structures that gave the members a sense of identity. It is crucial to note as the [14] and the [55] did that identity is a part of human security specifically community security. Thus, in the event that conflict destroyed identity, it as well eroded community safety and security. Burton, fortunately had in 1990, identified identity as a requirement for strengthened social order and social behaviour. The absence of the same (identity), hence, doesn't only lead to abnormalities in behaviour such as resorting to drug abuse but also anti-social behaviours that may be a ground for tension. The group insecurities created by the conflict had earlier been elaborated upon by [56] as such:

"apart from the unspeakable suffering to which the Acholi people have been subjected through violence, murders, body mutilation and child abductions, rape and pillage, the hallmark human tragedy in the conflict was massive ... the forced displacement of industrious agricultural communities from their pre-war ... homesteads into over 200 squalid camps ... was done hastily without prepara- 
tion ... camp life was not a refuge but a welter of human indignity and misery. It contributed to weakening of the cultural and traditional fabric which had provided a source of cohesion and a framework for families, clans and ethnic communities" [56].

The impact of the conflict on the social aspect of human security was echoed in an interview with the Principal Development Officer (quoted with permission) for the Northern Uganda Rehabilitation Program (NUREP); when he intimated:

"... the war lasted for more than 20 years ... people died in thousands and many were displaced ... on the government side, we lost soldiers ... Northern Uganda was the worst place to be in during the war... many people were forced into displacement camps, thousands of children were abducted - some killed and others serving in combat activities ..." (Interview, 26 ${ }^{\text {th }}$ August, 2018).

The Principal's views were confirmed by a respondent (R2) from a Civil Society Organization in his explanation that the war displaced people into places they did not know and had no knowledge on how to survive. Meantime, as a result of break down in social networks, the number of orphaned children increased. During the FGD, a participant who also served as a camp leader during the displacement explained that many orphans lack moral guidance and attributed the increase in theft to lack of parental care for the children. The truth in the former camp leader's submission was validated in an interview with the respondent from the Religious Initiative (R4) that: “... in some homes, all the parents were killed ... orphans are now being chased away by greedy uncles ..." The respondent also confirmed that widows had either been driven out of land or forced to be inherited so as to protect their land rights. [24] had earlier intimated that conflict does not only shatter the existing form of social cohesion but also profoundly alters the social values of the old and new generations and the LRA did just this!

\subsection{Cultural Erosion and Loss of Authority}

A respondent in a FGD, intimated that:

“... the war has spoilt our cultural norms ... girls were taught how to live ... the culture of respect has died ... the children who were guided have changed ... the war caused moral decay among the children ... they have all changed and do not respect elders anymore as they did in the past ... part of the reason is that parents were seen as useless in the camps because NGOs and humanitarian organizations became the providers ... they (parents) could no longer afford food, clothings and other basics for children ... every one became a beggar, parents were not seen as important anymore ..." (Focus Group Discussion, $8^{\text {th }}$ September, 2018).

Unfortunate it is that the war rendered the basic needs providers incapable of fulfilling their parental roles. Certainly, frustration resulting from unmet needs especially physiological needs creates room for conflict. With a facial expression that revealed disgust, $\mathrm{R} 3$ in an interview confirmed the cultural erosion: 
“... young boys and girls started to play sex-those in the age bracket of $15+$ started producing children they could not take care of ... children were exposed to sexual knowledge at a very young age ... members of different families were squeezed in the camps ... all were mixed up-boys, girls, all of them ... it didn't matter, we had to share because there was no enough shelter ..." (Interview, $26^{\text {th }}$ August 2018).

In a related tone, $\mathrm{R} 4$ decried the effect of the war on the social aspect of the Northern region. As a result of redundancy and alcohol abuse, many of the victims lost a sense self-respect especially as they returned to their huts. He intimated that:

"Acholi were very disciplined ... husband and wife would not share rooms with children ... due to war, parents misbehaved, started drinking, they cared no more ... women became like animals ... before the war, boys of 10 years and above would no longer sleep in their parents' hut ... they were expected to construct their own huts and would share these with their siblings ... girls would either sleep in the kitchen or in another hut ... adults had their own huts for privacy ... they sexually would meet without exposing the children to such acts ... the war upset everything ..." (Interview, $9^{\text {th }}$ September, 2018).

Due to conflict, traditional leaders who were displaced internally lost respect and authority as poverty rendered them hopeless and dependent like everybody else [57]. Without doubt, poverty threatens human security realization because it limits realization of freedom from want. The [15] explained that poverty leads to deficits in education, feeding and attainment of other human requirements. During the research, it was as well revealed that the patriarchal society in which the heads were men had changed as a result of empowerment by the NGOs and other humanitarian organizations to women-this however has an effect on the cultural values of the Acholi. In an interview, the sentiments were captured as below:

“... the war affected men's authority ... men went away and this has affected the culture ... women have become unruly and have now threatened cultural valued ... they are acting in ways that are not Acholi-like ... the NGOs have told them that they have rights and power ... they do what they want and no longer listen to their husbands ... this causes a lot of domestic violence and family break-ups ... in the end children grow with no parents ... they lack parenting and this explains why they are unruly ..." (Interview, $9^{\text {th }}$ September, 2018).

The link between conflict and the cultural erosion had earlier been elaborated upon by the [58]. The [58], when interviewing clan leaders and council officials found that women no longer practiced their traditional roles of cooking food, laundry, disciplining children but rather left the house without husband's permission and returned home late. Deeming such behaviour offensive, the interviewees submitted that men would beat their wives. The [58] documented the results of the events as such:

"Women were also beaten on grounds of refusing to have sex ... but a majority of women felt that men had justification to beat them regardless of the grounds ... 
men leave their wives because they are unruly hence creating many femaleheaded or single households ... because women are bigheaded, the men tell them to take their rights and leave and so they end up living alone in their own households ..." [58].

Fascinating though is that while most literature related to conflict studies often considers women as victims, the shifted power relations among men and women had significant implications for women. As the desk literature indicated women took central positions while men became disempowered as a result of property loss. In narrating the face of these changes in post-war Acholi wrote [59]:

"Women have to ensure family welfare as well as family development in the face of relatively diminished male contribution in real and symbolic terms ... with economic power, women had made a tremendous change in the management of household affairs. It has impacted on women's positions in terms of decision making and ownership/control of resources. The number of women taking the bulk of family decisions is now sizeable in Northern Uganda; this has also an impact on the general picture of women's power in the community ... the situation is one of relative empowerment of women both as individuals and as a collective..."

Despite this empowerment, as the discussion has indicated women are disproportionately affected by conflict especially as it further complicated property rights forcing them to remarry for security purposes.

\subsection{Public Service Collapse}

Without doubt, the outbreak of conflict exerts a lot of pressure on existing public infrastructure such as water and health facilities. Public servants do not only flee for their lives but often, even when conflict is over are unwilling to return to the previous areas of work. In most cases, the infrastructure is in dire need of rehabilitation, anyway. When responding to threats to human security as a result of conflict, many respondents referred to collapse of the health sector, destruction of water sources and breaking down the education system. The explanation below is informed by the respondents' submissions.

\subsubsection{Threats to Health}

The [15] included health security under the types of human security and listed thus, the following (deadly infectious diseases, unsafe food, malnutrition and lack of access to basic health care) as insecurities to the same. In a Focus Group Discussion with five participants, this was confirmed. A participant submitted:

"The health situation was appalling ... it was bad. Camps were all full to capacity, they were over-crowded and unclean ... we reached a point where it didn't matter anymore ... there were no toilets, no water, no proper accommodation ... even now, the health services are not good but at least' (FGD, 25 ${ }^{\text {th }}$ August, 2018).

A respondent from the 5 member FGD submitted that: “... People are not 
okay psychologically ..." Before he could complete his submission, another respondent in the same group cut in and confirmed:

“... due to abductions, there are high cases of HIVIAIDS among the girl children ... people are in a dilemma ... children were taught to do bad things ... even the elders were not spared ... you would be instructed to kill people that you knew - your neighbors ... if you refused you would also be killed. Children were told to drink blood of those they killed ... they cut the people and cooked the bodies and ate the flesh ... it was horrible" (FGD, 25 ${ }^{\text {th }}$ August, 2018).

That survivors are psychologically unwell confirmed the view by [31] that trauma comes as a result of witnessing the numbers injured, killed and traumatic sounds of gunshots and landmine blasts. Unfortunately, as the [14] documented and as R7 from the Resident District Commissioner's office acknowledged, trauma and psychological challenges often go unattended.

The views from the FGDs and statements from different authors were as well validated in an interview at Gulu Hospital during which the respondent expressed that:

"Due to war, there was a high number of old age people with mental problems ... as a result of bombs, there are high cases of hypertension and HIVI AIDS is still very high ... many youth today got exposed to sexual activities when still young, they are now battling with HVI AIDS and other sexually transmitted diseases" (Interview, 28 ${ }^{\text {th }}$ August, 2018).

Trauma can cause psychological insecurity, disrupt esteem and affect the victim's trust and personal relationships [60]. At worst, traumatic symptoms are expressed through depression, sleeping disorders and night mares among others.

Meanwhile, the high prevalence of HIV/AIDS and other sexually transmitted diseases are in conformity with the [58], which, 3 years before the implementation of the first Peace Recovery and Development Plan (PRDP) recorded that the prevalence levels of HIV/AIDS in Northern Uganda stood at $9 \%$ compared to the national percentages at $6.4 \%$. The situation, the [58] explained, was compounded by lack of drugs, lack of sensitization, inability by mothers to prevent mother-to-child transmission and lack of services such as emergency contraceptives or post-exposure propylaxes to prevent HIV transmission among camp rape victims.

It is not so startling to find that in Northern Uganda, the conflict led to massive spread of HIV/AIDS when one bears in mind that the LRA relied majorly on child soldiers for service. Apart from the soldiering activities, many children were also used to serve as sexual slaves to the older soldiers that many returned with children. Yet, apart from the health implications of conflict, access to water was equally limited.

\subsubsection{Compromising Water Access}

As expressed by the respondents, conflict had a huge impact on the existing water sources. In a FGD, for example, a participant submitted that:

"In the IDP camps, all water pumps were dry. Now, they are drilling new bore 
holes ... we reached a point where water was to be rationed among the thousands of people in the camp ... the sanitation was really poor ... drinking unboiled water, when it rained you would thank God but then you would worry about where you would hide for the night ... during the sunny weather, people would move long distances in search for water especially when the boreholes broke down ... other times, the taps would run for a shot period to allow people fetch the water ..." (FGD, $9^{\text {th }}$ September, 2018).

The water situation in the camps though was not so different from that in the urban areas. For example, the [58] documented that while in Gulu District, the availability of water from a protected source stood at $88.5 \%$, a person would only get 11.0 litres per day having waited for a mean period of 2 hours!

In another FGD of nine participants, a respondent intimated: "We used to have springs and wells and the water was fresh, the boreholes have rust ... these days tooth decay is common-even among the one crawling ..." In 2009, the [35] explained that conflict can lead to destruction of water sources due to bombings and affect sanitation generally later leading to diseases like diarrhoea. This is possible because during conflict, the chances of accessing safe and clean water become very narrow and minimal. Indeed, in 2012, the [61] documented that in Gulu, in the congested camps, each person only received an average of three litres of safe water as opposed to the recommended 20 litres. The [61] observed that: "the congestion in camps in combination with an acute shortage in latrines - there is one latrine for every 145 people in some camps-increases the possibility of faecal contamination of ground water" [61]. This, undoubtedly threatens health security. But just as conflict threatens health, so does it education as explained in the following section.

\subsubsection{Educational Deficits}

Conflict affects education due to attacks on students and teachers as well [37]. This was correlated during the research when, in a FGD in which a participant said:

"The LRA killed the education sector so much ... on the way to and from school, many children were abducted ... now they can't compete in the job market like in other regions ... and that's why we have a translator ... children were abducted from anywhere ... from and to school, on the way to the streams, even those in schools were abducted ... many became the fighters wives and those who refused would be killed, after the war, they have no skills to survive ..." (FGD, 25 ${ }^{\text {th }}$ August, 2018).

In 2002 , about 12,000 children were abducted by the LRA forcing them into servitude and missing out on education [62]. To confirm the statement, the [62] captured the story of a LRA child abductee, who, at 12 years was conscripted. In the story, the former captive was recorded thus: “... I was scared. I tried to run away but there were so many of them around us ... I heard that they were taking young children to Sudan to exchange them for guns ..." Certainly, education faced several challenges especially as children, in the periphery zones of Gulu 
town marched to the urban every evening and out every morning to escape conscription. The night commuters, as they were referred to suffered an education gap.

[36] remarked that conflict doesn't just lead to loss of years but also affects educational infrastructure, causes teacher shortages as a result of death and fleeing. [36]'s remarks were confirmed in an interview session with a top administrator of Lukodi primary school. Asked how war affected the education sector, she paused a bit and later exclaimed as though to say: what don't you know? After a while, she composed herself and narrated:

“... most of the schools were in camps where there were no chairs, desks... some were even destroyed. The children born during those days have a low level of understanding ... their morale is low ... since there is poverty, some teachers including me have become very aggressive. In the IDP camps, you would have more than 150 children-we struggled to write on the boards, the text books were looted, desks were destroyed and this makes handwriting very hard ... the grass thatched schools were burnt, teachers wouldn't commute, they wouldn't keep time ... they arrived late and left early ... many actually lost their lives while on the way ..." (Interview, $03^{\text {rd }}$ September 2018).

The above sentiments were supported in an interview session with R3 who explained that children during war lost out on education as they were taken to places they didnt know. In a similar manner, R5 explained that the war badly affected the education sector that in the post-war environment the number of the uneducated is high. The respondent narrated how the conflict affected education:

“... Without formal learning and with a high cost of living, survival has become difficult ... many youths today spent all their earlier years in the camps... you know the conditions in the camps ... many could not study because the make-shift classes were overcrowded ... that wasn't really education. Today, they have no reading and writing abilities ... of course when the war started, many fearing abductions dropped out of school hoping it won't take long ... it finally became part of life ..." (Interview, 27 ${ }^{\text {th }}$ August, 2018).

It is disheartening to record that conflict did not only affect education by increasing fears of abduction while to or even in school but also destroyed infrastructure, increased cases of orphan-hood and poverty making access to education rather a dream. Yet, just as education was compromised so was personal security.

\subsubsection{Criminality and Personal Insecurity}

[61] confirmed that the conflict in Northern Uganda, apart from displacing people and undermining social support systems, also caused an increase in crime, alcohol and drug abuse. In an interview with R3, he explained the contribution of alcohol and drug abuse to criminality and personal insecurity:

"There are high levels of alcoholism in Gulu ... everyone especially the middle-aged men are using alcohol and drugs in a manner like never before ... because of the increase in bars, even children have easy access to local brew and 
spirits ... many have abandoned farm work and with a system of hand-outs they got used to in the camps, men have become useless ... when they are drunk, they commit all sorts of crime-fighting at home, stealing, killing boda-boda cyclists ..." (Interview, $9^{\text {th }}$ September, 2018).

In another interview session with $\mathrm{R} 4$, it was explained that neither alcohol nor drugs could alone explain the security situation in the district in the post-conflict period. Instead, the respondent blamed the increase in crime and personal security threats to the conflict in which conscripted children were taught to steal, loot and kill. He narrated:

"LRA sent the children to steal ... in the past, we piled sim-sim in the garden, now if you do, someone will thank you for your work ... many children, especially those that are returning from IDPs are juvenile criminals ... crimes committed are sometimes petty, other times capital including drug abuse, gambling and theft ... sometimes violent fights and assault ... capital offenses are few but one boy killed his sister who refused to do what he had told her ..." (Interview, $9^{\text {th }}$ September, 2018).

Meantime, due to unemployment, many youths resorted to smoking marijuana and taking alcohol, a trend that had driven them into ruthlessness and criminality. In a bid to emphasize the increase in crime, the RDC further linked it to redundancy and dependency that was created by the war environment. He intimated that as people were displaced in camps, they had no activities, no fields for cultivation and only depended on handouts from humanitarian organizations. As a result, youths who respected elders have now become wild and this is due to betting, drug and alcohol abuse as well as indoctrination during the conflict, he submitted.

It is worthy reminding the reader that [15] listed personal security as an element of human security and listed physical violence, crime, domestic violence and child labor its [personal security] main threats. In Gulu, the commonly committed crimes were listed as: murder, theft, rape and defilement [63]. Contrary to connections between criminality and the conflict made by the respondents, others attribute the levels of insecurity and crimes to a boom in the economic activities in the district. Indeed, quoting the then Northern Region Police Spokesperson, [63] recorded that as a result of growth in the economy, many people found space in Gulu with hopes of securing some form of employment. It is not assuming too much to say that the economy indeed may have a role to play in the increase in crime. Undeniably, while trying to compose a FGD in Gulu town, the chairperson-Bus Park warned me: "Gulu has people from all walks of life... Kitgum, Apach, Nwoya ... everyone comes to see how to progress in life ... this is a centre of economic growth in the North".

\section{Conclusion}

The foregoing segment has discussed the threats to human security as a result of conflict. From the respondents' submissions, the war threatened human security in various ways ranging from personal, health, to community. It is worth noting 
that human insecurity threatens realization of human dignity and in turn affects human development Respondents specifically also alluded to a break down in social services and a rise in personal insecurity as a result of heightened criminality. It is critical that in the post-conflict era, the broken-down infrastructure is addressed to lessen the possibility of renewed conflict due to dissatisfaction with services that would in turn worsen the levels of human insecurity. Noteworthy, while political security is a component of human security, no mention was made of it specifically. When the District representative mentioned it, she instead linked it to poverty and argued that the district's political insecurity cannot be disconnected from its economic insecurity. Only one participant from the Acholi Religious Initiative in an interview made attempts to explain the impact of conflict on the environment but even then, did so in passing as he accused the "big men" from Kampala of "finishing the forests". To mitigate the conflict threats to human security, there is need for humanitarian organizations, working hand in hand with the Government to commit to restoring health services both in terms of human capital and infrastructural development. Such a move shall be critical in filling the human gaps in the service sector but also rebuild the broken-down infrastructure. Additionally, there should be deliberate investment in counselling services as a way of mitigating trauma. In equal measure, both Government and non-state actors should focus on revamping the educational services through recruitment of qualified staff and investment in educational materials such as furniture and books. To improve personal security, more qualified personnel in the security sector should be deployed in the Northern region and Gulu district specifically in order to manage the increasing levels of crime.

\section{Conflicts of Interest}

The authors declare no conflicts of interest regarding the publication of this paper.

\section{References}

[1] Ochola, F. (2007) How to Ensure Reparations Do Not Furter Stigmatize Victims Particularly Children Hague.

[2] Wallensteen, P. and Sollenberg, M. (1998) Armed Conflict and Regional Conflict Complexes 1989-1997. Journal of Peace Research, 35, 621-634.

[3] Human Security Report Project (2011) Human Security Report 2009/10: The Cause of Peace and the Shrinking Costs of War. Simon Fraser University, Canada.

[4] Michailof, S., Kostner, M. and Devictor, X. (2002) Post-Conflict Recovery in Africa: An Agenda for the African Region. Africa Region Working Paper Series, 301-24.

[5] Katine (2007) Background: The Lord's Resistance Army. https://www.theguardian.com/katine/2007/oct/20/about.uganda

[6] ACCS (2013) Northern Uganda Conflict Analysis. Kampala.

[7] USAID (1997) The Anguish of Northern Uganda: Results of a Field Based Assessment of a Civil Conflict in Northern Uganda. Kampala.

[8] Branch, A. (2010) Exploring the Root of LRA Violence: Political Crisis and Ethnic Politics in Acholi Land. In: The Lord's Resistance Army: Myth and Reality, Zed 
Books, London.

[9] Burton, J. (1990) Conflict: Human Needs Theory. Macmillan Press Ltd., Houndmills.

[10] Pia, E. and Diez, T. (2007) Conflict and Human Rights: A Theoretical Framework. SHUR1-301/07.

[11] Ramsbotham, O., Woodhouse, T. and Miall, H. (2011) Contemporary Conflict Resolution. 3rd Edition, Polity Press, London.

[12] Owen, T. (2008) The Uncertain Future of Human Security in the UN. International Social Science Journal, 59, 113-127.

[13] UNDP (1993) Human Development Report: People’s Participation. New York.

[14] UN (2003) Human Security Now. New York.

[15] United Nations (n.d.) Human Security in Theory and Practice. New York.

[16] Yahaya, A.B. and Tinab, M. (2015) Socio-Economic Effects of Armed Conflict on Women and Children in Bawku Municipality. UDS International Journal of Development, 2, 148-159.

[17] Leuven Centre for Research on Peace and Development (2011) A Typology of Post-Conflict Environments. CRPD Working Paper No. 1.

[18] United Nations Development Program (2004) Conflict Prevention Thematic Guidance Note. New York.

[19] Enzama, W. (2015) Reconstructing Post-War Local Economies: Institutional Dynamics and Small Holder Value Chain Interventions in Northern Uganda. International Institution of Social Studies, Erasmus University, Rotterdam.

[20] United Nations (2012) Peace Building through Justice for all and Human Rights.

[21] Office of the Prime Minister (2007) Peace Recovery and Development Plan for Northern Uganda (PRDP).

[22] Ministry of Education (2016) Education Abstract 2016. Kampala.

[23] Reinke, A.J. (2016) Gendering Peacebuilding in Post-Conflict Northern Uganda. Journal of Global Initiatives. Policy, Pedagogy, Perspectives, 10, 71-86.

[24] USAID (2008) Education and Fragility in Northern Uganda. Kampala. Educational Quality Improvement Program.

[25] African Capacity Building Foundation (2004) Reconstruction and Capacity Building in Post-Conflict Countries in Africa: A Summary of Lessons of Experience from Mozambique, Rwanda, Sierra Leone and Uganda. ACBF, Harare.

[26] Adan, A.M. (2015) Clan Politics in Somalia: Consequences of Culture or Colonial Legacy? Mogadishu Somali Think Tank.

[27] Ohiorhenuan, J.F.E. (2011) Post Conflict Recovery: Approaches, Policies and Partnerships. CRPD, Working Paper, 1-18.

[28] Kenneth, O. and Nicodemus, M. (2014) Stakeholder Perspectives on Priorities for Post Conflict State Building and Peace Building in South Sudan. Africa Peace and Conflict Journal, 7, 14-28.

[29] World Health Organization (2013) Post-Conflict Recovery as an Impetus for Strengthening Health System Resilience in Africa: Experiences and Lessons from the Northern Ugandan Humanitarian Crisis. Geneva.

[30] Murray, C.J.L., King, G., Lopez, A.D., Tomijima, N. and Krug, E.G. (2002) Armed Conflict as a Public Health Problem. Education and Debate, 324, 346-349.

[31] Centre for Research and Epidemiology of Disasters (2002) Armed Conflict and Pub- 
lic Health: A Report on Knowledge and Knowledge Gaps. CRED, Louvain, Brussels.

[32] Buvinic, M., Das Gupta, M., Casabonne, U. and Verwimp, P. (2012) Violent Conflict and Gender Inequality: An Overview. Brighton Institute of Development Studies, HICN Working Paper 129.

[33] Dyregrov, A., Gupta, L., Gjestad, R. and Mukanoheli, E. (2000) Trauma Exposure and Psychological Reactions to Genocide among Rwandan Children. Journal of Traumatic Stress, 13, 3-21.

[34] MSF-Médecins Sans Frontières (2004) Life in Northern Uganda: All Shades of Grief and Fear.

[35] UNICEF (2009) Machel Study 10-Year Strategic Review: Children and Conflict in a Changing World. New York.

[36] UNESCO (2011) The Hidden Crisis: Armed Conflict and Education 2010. Paper Commissioned for the EFA Global Monitoring Report.

[37] Gates, S. (2004) Primary Schooling as Protective and Endangering: The Case of Education in War-Affected Gulu District Electronic. Theses and Dissertations, Paper 232.

[38] Omoeva, C., Moussa, W. and Hatch, R. (2018) The Effect of Armed Conflict on Educational Attainment and Inequality. Connecticut Education Policy and Data Centre, Connecticut, Washington, D.C.

[39] Omilusi, M. (2016) The Multi-Dimensional Impacts of Insurgency and Armed Conflict on Nigeria. Asian Journal of Social Sciences, 16, 29-39.

[40] Hovil, L. (2012) Gender, Transitional Justice and Displacement: Challenges in Africa's Great Lakes Region. LSE Project on Internal Displacement, Brookings, London.

[41] Plümper, T. and Neumayer, E. (2006) The Unequal Burden of War: The Effect of Armed Conflict on the Gender Gap in Life Expectancy. International Organization, 60, 723-754.

[42] Sobh, R. and Perry, C. (2006) Research Design and Data Analysis in Realism Research. European Journal of Marketing, 40, 1194-1209.

[43] Alessandrini, M. (2012) Non-Positivist Approaches to Research in the Third Sector: Empowered Policy Making. ISTR 10 th International Conference, Universita Degli Studi Di Siena, Siena, Italy, 10-13 July 2012, 1-17.

[44] Andrew Sayer, R. (1992) Method in Social Sciences: A Realist Approach. Routledge, London.

[45] Strauss, A. and Corbin, J. (1990) Basics of Qualitative Research: Grounded Theory Procedures and Techniques. Sage Publications, Thousand Oaks, CA.

[46] Creswell, J.W. (2007) Qualitative Inquiry and Research Design: Choosing among Five Approaches. 2nd Edition, Sage Publications, Thousand Oaks, CA.

[47] Catholic Relief Services (2004) Northern Uganda: The Forgotten War. Catholic Relief Services. Baltimore, MD.

[48] Whitehead, D. (2013) Sampling Data and Data Collection in Qualitative Research.

[49] Denscombe, M. (2010) The Good Guide for Small Scale Social Research Projects. 4th Edition, Open University Press, Berkshire, England.

[50] Flick, U. (2009) An Introduction to Qualitative Research. 4th Edition, Sage Publications, Oliver's Yard, London.

[51] Flick, U. (2009) An Introduction to Qualitative Research.

[52] Uganda Human Development Report (2015) Unlocking the Development Potential of Northern Uganda. UNDP, Kampala. 
[53] Gulu Gulu District Local Government (2012) Gulu District Statistical Abstract for $2012 / 2013$.

[54] Makerere Institute of Social Research (2011) From Camp to Slum: The Politics of Urban Displacement in Gulu Town, Uganda. Kampala, Working Paper No. 2.

[55] UNDP (1994) Human Development Report: New Dimensions of Human Security. New York

[56] Ministry of Foreign Affairs (2010) Exploring the Security-Development Nexus: Perspectives from Nepal, Northern Uganda and Sugago Finland.

[57] World Bank (2008) Northern Uganda Land Study-Analysis of Post-Conflict Land Policy and Land Administration: A Survey of IDP Return and Resettlement Issues and Lessons-Acholi and Lango Sub Regions. Kampala.

[58] Humanitarian Policy Group (2010) Humanitarian Exchange. 36.

[59] Burina, D.A. and Burina, E.A. (2016) Mental Health and Psychosocial Support in Areas Affected by Conflict: Review of Programs in Chechen Republic. Archives of Psychiatry \& Psychotherapy, 3, 40-47.

[60] International Displacement Monitoring Centre (2012) Uganda: Need to Focus on Returnees and Remaining IDPs in Transition to Development. Geneva.

[61] Li, K. and Chinyama, V. (2007) Surviving Abduction in Uganda's Civil Conflict. https://www.unicef.org/protection/uganda_27679.html

[62] Olaka, D. (2010) Crimes Rates Soar in Gulu.

[63] Grasa, R. and Mateos, O. (2010) Conflict, Peace and Security in Africa: An Assessment and New Questions after 50 Years of African Independence. Barcelona Institut Catala Internacional Per La Pau, ICIP Working Papers. 